\title{
The mRNA level of the transforming growth factor $\beta 1$ gene, but not the amount of the gene product, can be considered as a potential prognostic parameter in inflammatory bowel diseases in children
}

\author{
Anna Liberek • Zbigniew Kmieć • Dorota Kartanowicz • \\ Piotr M. Wierzbicki • Marcin Stanisławowski • \\ Lucyna Kaszubowska • Grażyna Luczak • \\ Magdalena Góra-Gębka • Piotr Landowski • \\ Agnieszka Szlagatys-Sidorkiewicz • Tomasz Liberek • \\ Barbara Kamińska • Joanna Jakóbkiewicz-Banecka • \\ Grzegorz Węgrzyn
}

Accepted: 25 April 2012 / Published online: 15 May 2012

(C) The Author(s) 2012. This article is published with open access at Springerlink.com

\begin{abstract}
Purpose Transforming growth factor $\beta 1$ (TGF- $\beta 1$ ) plays a role in cell proliferation and differentiation, and it can modulate immune response. In this work, we asked whether levels of either TGF- $\beta 1$ or mRNA of the corresponding
\end{abstract}

Electronic supplementary material The online version of this article (doi:10.1007/s00384-012-1489-4) contains supplementary material, which is available to authorized users.

A. Liberek · G. Łuczak · M. Góra-Gębka · P. Landowski ·

A. Szlagatys-Sidorkiewicz $\cdot$ B. Kamińska

Department of Pediatrics, Pediatric Gastroenterology,

Hepatology and Nutrition, Medical University of Gdańsk,

Nowe Ogrody 1-6,

80-803 Gdańsk, Poland

Z. Kmieć • D. Kartanowicz • P. M. Wierzbicki •

M. Stanisławowski $\cdot$ L. Kaszubowska

Department of Histology, Medical University of Gdańsk,

Debinki 1,

80-211 Gdańsk, Poland

T. Liberek

Department of Nephrology, Transplantology

and Internal Medicine, Medical University of Gdańsk,

Dębinki 7 ,

80-211 Gdańsk, Poland

J. Jakóbkiewicz-Banecka • G. Wegrzyn $(\bowtie)$

Department of Molecular Biology, University of Gdańsk,

Kładki 24,

80-822 Gdańsk, Poland

e-mail:wegrzyn@biotech.univ.gda.pl gene in plasma or tissue can be useful in diagnosing and/ or monitoring of the clinical course of inflammatory bowel diseases (IBD).

Methods The study group consisted of 104 pediatric patients with IBD: 36 with Crohn's disease (CD) and 68 with ulcerative colitis (UC); 42 children represented the control group. TGF- $\beta 1$ levels in plasma and intestinal mucosa were estimated by ELISA and immunohistochemistry (IHC), respectively. Levels of $T G F-\beta 1$ mRNA were determined by reverse transcription and real-time PCR.

Results In patients with IBD, and in subgroups with $\mathrm{CD}$ and UC, no significant differences in the TGF- $\beta 1$ level in plasma and tissue were found relative to the control group. These variables were not dependent on the stage of the disease, its activity or severity of endoscopic and histopathological findings. TGF- $\beta 1 \mathrm{mRNA}$ levels were significantly higher in tissue samples withdrawn during the relapse of the disease than in those taken during the remission or in the control group. However, no correlation between TGF- $\beta 1$ plasma levels and $T G F-\beta 1$ mRNA amount in the intestinal mucosa was observed.

Conclusions The TGF- $\beta 1$ mRNA level, but not the amount of the gene product, was significantly increased in the pathologically changed tissue during the relapse of IBD. We suggest that this parameter might be considered as a potential prognostic value when assessing IBD in children.

Keywords Inflammatory bowel disease $\cdot$ Transforming growth factor $\beta 1$ (TGF- $\beta 1$ ) · Children · Gene expression 


\section{Introduction}

Transforming growth factor $\beta$ (TGF- $\beta$ ), especially its isoform 1 , is known to be one of the major factors involved in immunological homeostasis. Biological activity of TGF- $\beta$ consists of effects on cell proliferation and maturation or immunomodulation [1-3]. Within particular organs and tissues, TGF- $\beta$ is involved in regenerative processes and upon some conditions may be responsible for pathological fibrosis [4-6]. Long-term immunoregulatory disturbances are proved to play a crucial role in the pathogenesis of numerous diseases [4-9], thus TGF- $\beta$ appears to be of great interest in contemporary studies. Either insufficiency or hyperactivity of TGF- $\beta$ may be responsible for some diseases, particularly due to its influence on immune response and regenerative processes. Some clinical and experimental studies indicated the role of TGF- $\beta$ in chronic inflammatory diseases, especially those of the bowels [10-14].

In the course of chronic inflammatory bowel diseases, the cicatricial changes within the bowel appear to be related to the activity of TGF- $\beta$, which is responsible for the fibrogenesis. However it still remains unknown whether an increased amount of TGF- $\beta$ in the inflamed tissue is the cause or only an innocent response for the insult and damage of the tissue related to the disease. Damage of the tissue is known to be one of the major factors responsible for the activation of the TGF- $\beta 1$ gene and increased production of this cytokine in site $[15,16]$. One may also assume that chronic inflammation is determined by the deficiency of TGF- $\beta$ biological activity. It was reported that mice lacking TGF- $\beta$ activity presented with multi-organ inflammatory and necrotic changes shortly after birth $[12,17]$.

Within the immune system, TGF- $\beta 1$ plays an immunosuppressive role preventing autoimmune and chronic inflammatory diseases. It inhibits the processes of activation of autoreactive lymphocytes $\mathrm{T}$, production of auto-antibodies, and thus, the self-antigens damage $[18,19]$. The wide range of data indicates the main role of altered function of cytokines, including TGF- $\beta 1$, in the pathogenesis of chronic inflammatory diseases, thus, further studies, especially in children, appear to be warranted $[20,21]$. The aim of the study was to evaluate the role of TGF- $\beta 1$ in the pathogenesis of inflammatory bowel diseases (IBD) and to assess whether levels of either TGF- $\beta 1$ and/or mRNA of its gene, in either plasma or tissue expression, can be useful in diagnosing and/or monitoring of the clinical course of these diseases.

\section{Methods}

Patients

The study group consisted of 104 patients with IBD, including 36 with Crohn's disease (CD) and 68 with ulcerative colitis (UC), at the age 1.5-18.4 years (mean, $13.0 \pm 4.5$; median, 14.5). Forty-two children represented the control group, which consisted of 20 girls and 22 boys at the age 2.0-18.0 years (mean, 11.0 \pm 5.0 ; median, 11.0 ), who underwent endoscopy because of the events of the gastrointestinal (GI) bleedings (this relatively high number of pediatric patients with GI bleedings resulted from the fact that the Department of Pediatrics, Pediatric Gastroenterology, Hepatology and Nutrition of the Medical University of Gdańsk serves as one of pediatric gastroenterology reference centers for Northern Poland, covering relatively large population); in this group of patients, inflammatory processes, immune disorders, malignancies, and nutritional abnormalities were excluded. None of the patients received immuno-modulating drugs at least 6 months prior to the study. Most IBD patients were treated with anti-inflammatory drugs (e.g., 5-amino salicylic acid). Only minority, with more severe disease course or during the relapse, used immunosuppresants (e.g., steroids or azathioprine). However, since we have detailed data on drug therapies only for a part of patients, this parameter was not analyzed in this study.

\section{Clinical parameters and samples' collection}

Endoscopic and histological classifications of intestinal mucosa were performed according to the Porto criteria [22]. Among IBD patients, severities of CD and UC were estimated according to the Hyams scale (Pediatric Crohn's Disease Activity Index) and the Truelove-Witts scale, respectively $[23,24]$.

In patients in the acute phase of the IBD, both blood and bowel tissue samples were obtained while in those in remission, the level of TGF- $\beta$ in the serum was assessed. In a few patients, when the control endoscopy was mandatory, the level of TGF$\beta$ was measured also in the bowel tissue. All samples were obtained while performing obligatory diagnostic procedures.

\section{Inflammatory parameters}

The following inflammatory parameters were determined for all subjects: C-reactive protein level (CRP), erythrocytes sedimentation rate, and full blood count.

\section{Determination of TGF- $\beta 1$ level}

The TGF- $\beta 1$ level in plasma was estimated by ELISA (Quantikine TGF- $\beta 1$ R\&D Systems, USA), according to manufacturer's instructions. Amount of the TGF- $\beta 1$ protein in the intestinal mucosa was estimated by immunohistochemistry (IHC; Vectastain ABC Kit, Vector Laboratories, USA) and microscopic observations at the final magnifications of $\times 200$ and $\times 400$. The results were described in a semi-quantitative scale $(0,1+, 2+$, and $3+)$. 
Measurement of mRNA levels

The mRNA level in the intestinal tissue was determined by reverse transcription and Real-Time PCR. Total RNA was isolated by employing the Total RNA Prep Plus kit (A\&A Biotechnology, Poland), according to manufacturer's instructions. Concentration and quality of RNA samples were determined spectrophotometrically (Smart Spec 3000 apparatus, Bio-Rad, USA). One microgram of RNA, $0.25 \mu \mathrm{g}$ of oligo $\mathrm{T}_{18}$, and M-MLV enzyme (Promega, Madison, WI, USA) were used for reverse transcription in total volume of $10 \mu \mathrm{l}$. The qPCR reaction contained $0.4 \mu \mathrm{l}$ cDNA, $180 \mathrm{nM}$ each primer and iQSybrGreen Supermix kit (Bio-Rad) and was performed in iCycler iQ (Bio-Rad) in total volume of $20 \mu \mathrm{l}$. Primers for $T G F-\beta 1$ and $A C T B$ were designed de novo using Primer3Plus based on BLAST, ENSMBL, and AceView databases; TGF- $\beta$ 1: 5'-CAG CAA CAA TTC CTG GCG ATA CC and TGF $\beta-2,5^{\prime}-$ CGA AAG CCC TCA ATT TCC CCT C, bact1-1, 5'-TGT GCC CAT CTA CGA GGG GTA TGC, and bact1-2, 5'GGT ACA TGG TGG TGC CGC CAG ACA. The reactions were run in triplicates and the obtained data were averaged followed by data analysis calculated with iQ ver. 3.1 software (Bio-Rad). The ACTB gene was used as a control to normalize the values in common $\Delta \Delta C_{\mathrm{t}}$ quantification method $[25,26]$.

\section{Statistical analysis}

Statistical analysis of the results was performed using nonparametric tests: the Mann-Whitney test for comparison of two groups, the ANOVA Kruskal-Wallis test for comparison of several groups, and the Spearman correlation test. For qualitative parameters, the Pearson's $\chi^{2}$ test was used, with Yates correction if $n<10$. The results were considered statistically significant when $p<0.05$. The calculations were performed employing Statistica 7 software (StatSoft Inc., OK, USA).

\section{Ethical considerations}

This study was approved by the Independent Bio-Ethical Committee for Research at the Medical University of Gdańsk (NKEBN/13/2004). Informed consent forms of patients and controls (or their parents) were obtained.

\section{Results}

TGF- $\beta 1$ plasma level

In the studied group of patients, the TGF- $\beta 1$ plasma levels were in the range of $0.11-55.10 \mathrm{ng} / \mathrm{ml}$ (mean, $7.01 \pm$
$9.37 \mathrm{ng} / \mathrm{ml}$; median, $3.51 \mathrm{ng} / \mathrm{ml}$ ) (Table 1). No statistically significant differences between the TGF- $\beta 1$ plasma levels in IBD patients and control group were noted, although $p$ value was 0.06 . No statistically significant differences were also observed between the UC and the $\mathrm{CD}$ patients and the control group $(p=0.16)$ (Table 1).

No statistically significant differences were noted among the TGF- $\beta 1$ plasma levels in the particular phases of the disease (mean TGF- $\beta 1$ plasma levels were as follows: at the time of diagnosis, $8.59 \mathrm{ng} / \mathrm{ml}$; at the relapse, $7.22 \mathrm{ng} / \mathrm{ml}$; and at the remission, $7.91 \mathrm{ng} / \mathrm{ml}$ ), and in the control group (6.3 ng/ml; $p=0.22)$, as well as in the particular subgroups, the $\mathrm{UC}(p=0.55)$ and the $\mathrm{CD}(p=0.65)$ patients. Moreover, no statistically significant differences were found between TGF- $\beta 1$ plasma levels at particular activity grades of IBD relative to the control group $(p=0.27)$. The same was true when UC and CD were considered separately, relative to the control ( $p=0.13$ and 0.23 , respectively).

In the studied group of children with IBD, the TGF- $\beta 1$ plasma levels showed no correlation with endoscopic $(p=$ $0.42)$ and histopathological $(p=0.55)$ activity of the disease. Furthermore, no statistically significant correlations of TGF$\beta 1$ plasma levels with CRP, SR, WBC, and platelet count were noted (data not shown).

\section{TGF- $\beta 1$ levels in the intestinal tissue}

The IHC studies were performed in intestinal tissue samples in 72 children (IBD, 53; UC, 37; CD, 16; and the control group, 19). The intensities of the IHC reaction specific to TGF- $\beta 1$ were assessed in the semi-quantitative scale as follows: $1+$ in $15(19.2 \%)$ children, $2+$ in $39(50 \%)$, and $3+$ in 24 patients $(30.8 \%)$. No statistically significant differences were noted between the intensity of IHC in the IBD patients and in the control group and in the particular groups of CD and UC patients (data not shown).

In the studied group of children, the intensity of IHC showed no correlation with the disease activity neither in the

Table 1 Plasma concentration of TGF- $\beta$ in the study groups and subgroups

\begin{tabular}{lrrrrrr}
\hline \multirow{2}{*}{ Group } & Number & \multicolumn{5}{l}{ TGF- $\beta 1$ concentration (ng/ml) } \\
\cline { 3 - 7 } & & Mean & Median & Min & Max & SD \\
\hline Control & 42 & 6.96 & 2.79 & 0.54 & 55.10 & 11.61 \\
IBD & 104 & 7.71 & 3.72 & 0.20 & 43.14 & 9.05 \\
UC & 68 & 7.86 & 3.54 & 0.20 & 43.14 & 9.83 \\
CD & 36 & 7.46 & 4.43 & 0.72 & 30.45 & 7.49 \\
\hline
\end{tabular}

Statistical analysis: control vs. IBD $(p=0.06)$; CD vs. UC $(p=0.16)$

${ }^{a}$ Results from three independent measurements in each sample (including RNA extraction) are presented

$S D$ standard deviation 
whole IBD group nor in the particular groups of CD and UC patients (data not shown).

mRNA levels of the $T G F-\beta 1$ gene

The mRNA levels of the $T G F-\beta 1$ gene in the intestinal tissue in the studied group of children are presented in Table 2. The levels in the inflamed intestinal tissue were significantly higher in IBD patients than in the control group $(p=0.002)$. However, the mRNA levels in the tissue samples obtained from macroscopically unchanged intestinal regions in the IBD patients in the active phase of the disease showed no significant differences relative to the control group $(p=0.12)$.

Like in the whole IBD group, in the UC patients the mRNA levels in the macroscopically changed intestinal tissue were statistically higher than in the control group $(p=0.02)$, and at the edge of statistical significance in the $\mathrm{CD}$ patients in comparison with the control group $(p=0.05)$. No statistically significant differences were noted between the mRNA levels in the groups of CD and UC patients $(p=1.00)$. Furthermore, the mRNA levels of the TGF- $\beta 1$ gene in tissue samples obtained from patients in the active phase of the disease, but from the macroscopically unchanged intestinal regions, showed no statistically significant differences with the control group and in both CD and UC groups $(p=0.26)$.

Moreover, we have analyzed samples from 41 IBD patients (28 UC patients and $13 \mathrm{CD}$ patients) in which samples of the intestinal tissue were withdrawn during colonoscopy at the active phase of the disease from both changed and unchanged areas (Fig. 1). Statistically significant differences were found between $T G F-\beta 1$ mRNA levels in changed and unchanged tissues when the whole group of IBD was analyzed $(p<0.001)$ as well as in the CD and UC subgroups ( $p<0.001$ in both cases), namely, the levels in the changed tissue samples were higher than in unchanged tissue samples (Fig. 1).

The comparison of TGF- $\beta 1 \mathrm{mRNA}$ levels in particular phases of the disease (Fig. 2) showed significantly higher values in the relapse of the disease relative to both remission $(p=0.01)$ and the control group $(p=0.04)$. However, no statistically significant differences were noted between the mRNA levels in the remission and the control group ( $p=$ 0.99 ), and between the mRNA levels in samples withdrawn at the time of diagnosis and (1) the time of remission ( $p=$ $0.99)$, (2) the relapse $(p=0.12)$, and (3) the control group $(p=0.80)$.

No statistically significant differences were noted in the whole IBD group, and in both CD and UC subgroups, when the mRNA levels in macroscopically changed intestinal tissues at the active phase of the disease were tested in relation to the endoscopic (IBD, $p=0.42 ; \mathrm{CD}, p=0.40$; and $\mathrm{UC}, p=0.32$ ) and histopathological (IBD, $p=0.55$; CD, $p=$ 0.95 ; and UC, $p=0.23$ ) changes.

Interestingly, no statistically significant correlation was observed between the TGF- $\beta 1$ plasma levels and the $T G F$ $\beta 1$ mRNA levels in the macroscopically changed intestinal tissue in the group of IBD patients $\left(R_{\mathrm{s}}=0.19 ; p=0.07\right)$ and in both $\mathrm{CD}$ and UC subgroups (for $\mathrm{CD}, R_{\mathrm{S}}=0.07 ; p=0.71$ and for $\left.\mathrm{UC}, R_{\mathrm{s}}=0.24 ; p=0.08\right)$.

\section{Discussion}

The wide range of cytokines plays a significant role in the pathogenesis of the chronic inflammatory bowel diseases, thus, intensive research estimating their levels either in the blood or in the inflamed tissues employing immunohistochemical and molecular methods, is being conducted [20, 27-31]. Furthermore, signaling pathways of particular cytokines are being assessed at the molecular level [32, 33]. Most of the data are related to the blood levels of particular cytokines due to the less invasive procedures of obtaining blood samples comparing to obtaining tissue samples and availability of numerous ELISA kits suitable for estimation of cytokine levels in the blood [20, 28, 31, 33].

Table $2 T G F-\beta 1$ mRNA levels in intestinal tissue of the control group and the study groups

\begin{tabular}{|c|c|c|c|c|c|c|}
\hline \multirow[t]{2}{*}{ Sample } & \multirow[t]{2}{*}{ Number } & \multicolumn{5}{|c|}{$T G F-\beta 1$ mRNA level (arbitrary units) ${ }^{\mathrm{a}}$} \\
\hline & & Mean & Median & Min. & $\operatorname{Max}$ & SD \\
\hline Control & 42 & 0.08596 & 0.04028 & 0.00103 & 0.82469 & 0.16012 \\
\hline IBD-affected area & 90 & 0.15040 & 0.06569 & 0.00068 & 1.59320 & 0.21443 \\
\hline $\mathrm{UC}$ & 57 & 0.15512 & 0.07289 & 0.00068 & 0.85378 & 0.18372 \\
\hline $\mathrm{CD}$ & 33 & 0.15782 & 0.06569 & 0.00296 & 1.59320 & 0.27999 \\
\hline $\begin{array}{l}\text { IBD-unaffected area } \\
\text { (active stage of disease) }\end{array}$ & 41 & 0.03852 & 0.02244 & 0.00108 & 0.30119 & 0.06087 \\
\hline
\end{tabular}

${ }^{a}$ Results from three independent measurements in each sample (including RNA extraction) are presented. Statistical analysis: control vs. IBD (affected area; $p=0.002$ ); control vs. IBD (unaffected area; $p=0.12$ ); control vs. UC (affected area; $p=0.02$ ); control vs. CD (affected area; $p=0.05$ ); $\mathrm{UC}$ vs. CD (affected area; $p=1.0$ ) 
Fig. $1 T G F-\beta 1$ mRNA level in samples from the affected and unaffected areas during active stage of disease in the IBD group (collective data). a Values for the whole group and b results for individual patients. Results from three independent measurements in each sample (including RNA extraction) are presented. In (a), the difference between values presented for affected and unaffected areas was statistically significant $(p<0.001)$
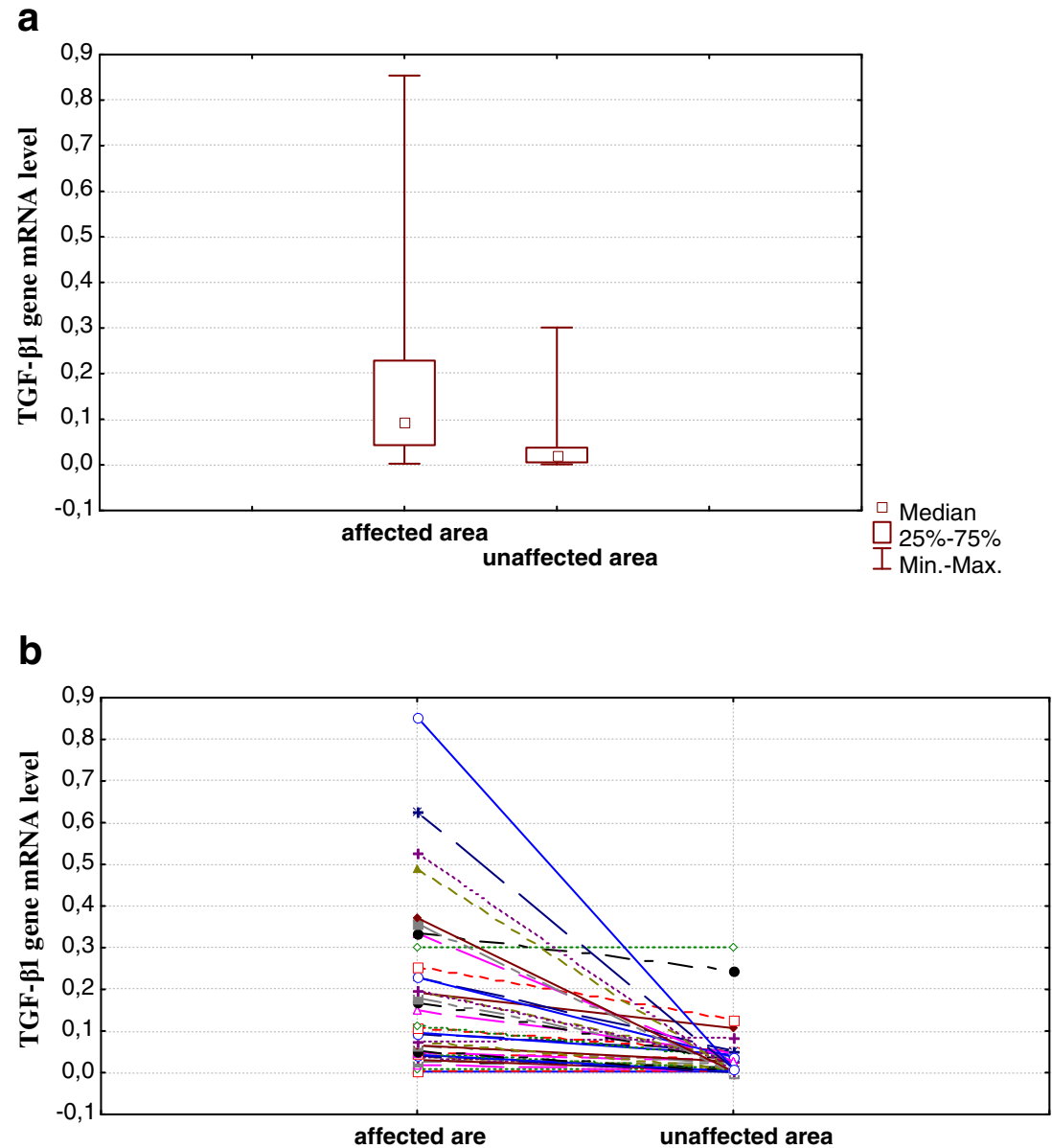

Data referring the role of TGF- $\beta 1$ in the pathogenesis of the chronic inflammatory bowel disease, especially in children, are rather scarce $[20,21]$. In the group of children described in this report and suffering from chronic inflammatory bowel diseases, the TGF- $\beta 1$ plasma levels showed no significant differences in both $\mathrm{CD}$ and UC patients and the control group. Medical reports on this topic are equivocal. Sturm et al. [34] presented no statistically significant

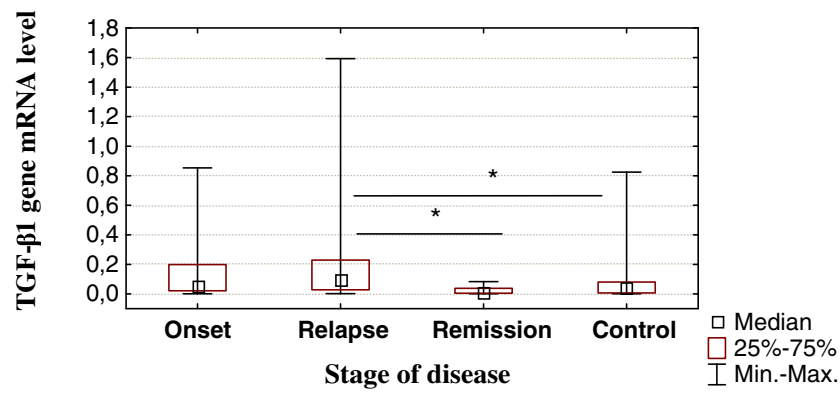

Fig. $2 T G F-\beta 1$ mRNA level at different stages of the disease in IBD patients and in the control group. Results from three independent measurements in each sample (including RNA extraction) are presented. Statistically significant differences are marked by asterisks (the $p$ values were 0.01 and 0.04 for comparison between relapse vs. remission and remission vs. control, respectively) differences between the TGF- $\beta 1$ and HGF (hepatocyte growth factor) plasma levels in patients with IBD and the control group. However, in other study, similarly to our results, the tendency to the higher TGF- $\beta 1$ plasma levels in the IBD patients was noted [34]. No statistically significant differences between the TGF- $\beta 1$ plasma levels in patients with $\mathrm{CD}$ and children with $\mathrm{UC}$, were also noted in the research by Kader et al. [20]. In that study, plasma levels of over 70 cytokines and growth factors were estimated in the group of 88 children with IBD ( 65 with UC and 23 with $\mathrm{CD}$ ). In patients with $\mathrm{CD}$, plasma levels of four cytokines, PLGF (placenta growth factor), IL-7, Il-12p40, and TGF- $\beta 1$ were significantly higher in the remission than in the active phase of the disease. However, in patients with UC, such differences were proved to be related only to one cytokine, IL-12p40 [20]. Those authors put stress on the distinct profile of the cytokines' activity in patients with $\mathrm{CD}$ and patients with UC, which may be mainly explained by Th1 cell involvement in the immune response in $\mathrm{CD}$ patients, and Th2 in UC patients. Furthermore, no decrease in the cytokines' plasma levels in the course of the clinical improvement was noted [20].

In the group of patients studied in this work, the TGF- $\beta 1$ plasma levels showed no correlation with the clinical phase 
of the disease. It might be partly explained by rather low severity of the disease at the time of diagnosis in the studied group of children. Sturm et al. [34] presented no significant differences between TGF- $\beta 1$ plasma levels in 74 patients with IBD ( 28 with UC, 45 with CD) in relation to particular phases of the disease and to the control group. Our data showed also no significant correlation between the TGF- $\beta 1$ plasma levels and the results of the laboratory blood tests.

Besides the TGF- $\beta 1$ plasma levels, the intestinal tissue levels of TGF- $\beta 1$ were estimated by IHC. No statistically significant differences were noted between the intensity of IHC in the IBD patients and in the control group, and in particular subgroups of CD and UC patients. Previously, Lawrence et al. [35] observed the diverse pattern of the IHC intensity in relation to the type of IBD: in the patients with $\mathrm{CD}$, the intramural IHC was the most intense, while in the patients with UC the highest signals were detected in submucosal and within the lamina propria. The intensity of the IHC correlated with the inflammatory infiltration in all patients and it finally appeared to be the main factor affecting the IHC [35]. Numerous authors suggested a role for some other TGF- $\beta$ isoforms in the pathogenesis of IBD. Kazanawa et al. [36] showed no intestinal tissue expression of the $T G F-\beta 1$ gene in adults with CD and UC. However in some of them, TGF- $\beta 2$ and TGF- $\beta 3$ isoforms were detected along with the intestinal tissue production of FGF (fibroblast growth factor) and VEGF (vascular endothelial growth factor) [36]. Noteworthy, McKaig et al. [37] reported a similar expression of the $T G F$ $\beta 1$ gene in cell cultures of myofibroblasts obtained from macroscopically unchanged or inflamed intestinal regions, in both CD and UC patients. Furthermore, the presence of other TGF isoforms was detected in cell cultures of myofibroblasts obtained from inflamed intestinal regions: TGF- $\beta 2$ mainly in CD patients and TGF- $\beta 3$ in UC patients [37]. In intestinal myofibroblast cultures from CD patients, intense cell proliferation, along with increased tissue inhibitors of metalloproteinases production was observed, what appeared to be responsible for the predisposition to fibrosis and intestinal strictures in this group of patients [38].

Our data showed that the mRNA levels in the intestinal tissue were significantly higher in the IBD patients in the active phase of the disease than in the control group. These differences were prominent when tissue samples were obtained from the macroscopically changed regions. The tissue samples obtained from the patients in the active phase of the disease, but from the macroscopically unchanged intestinal regions, showed no statistically significant differences relative to the control group. This was also true for both CD and UC subgroups. Del Zotto et al. [39] showed similar relationships estimating the TGF- $\beta 1$ levels in cell cultures. Contrary to the CD patients, monocytes and lymphocytes $\mathrm{T}$, obtained from the lamina propria of UC patients, produced more TGF- $\beta 1$ than control cells [39].
It is intriguing that despite the above mentioned differences in the levels of $T G F-\beta 1$ mRNA, no such differences were detected in levels of the gene product (the TGF- $\beta 1$ protein) in both plasma and tissue samples. The lack of correlation between the tissue mRNA and the plasma protein levels might be explained by possible specificity of the effects for $T G F-\beta 1$ expression, restricted solely to the pathologically changed tissue. Such a hypothesis may be corroborated by the fact that $T G F-\beta 1$ mRNA levels in the inflamed intestinal tissue were significantly higher in IBD patients than in the control group, while analogous values measured in tissue samples obtained from macroscopically unchanged intestinal regions of the same patients showed no significant differences relative to the control group. A lack of the difference in the levels of the TGF- $\beta 1$ protein between IBD patients and the control group, in the light of significantly different corresponding mRNA levels, could arise from the use of a semi-quantitative method for determination of the protein level. Alternatively, such a discrepancy might result from a putative, extensive posttranscriptional regulation of the $T G F-\beta 1$ gene expression.

Our results indicated that $T G F-\beta 1$ mRNA levels in the intestinal tissue were significantly higher in tissue samples obtained at the time of relapse than in tissue samples obtained at the time of diagnosis. This may be due to the signaling pathways disturbances and defects of regulatory mechanisms essential in the active phase of the disease [40]. Since serial probing in different activity stages of the disease is not recommended if there is no therapeutic consequences, our results cannot be applied directly in estimating the progress of the disease. However, one can speculate that if tissue samples were withdrawn during medical procedures anyway, then estimation of TGF- $\beta 1$ mRNA levels might be considered as a potential prognostic value of the course of the disease, indicating unfavorable prognosis in the case of increased levels.

Acknowledgments This work was supported by the Ministry of Science and Higher Education, Poland (project grant no. 2P05E 125 27).

Conflict of interest The authors declare that they have no conflict of interest.

Open Access This article is distributed under the terms of the Creative Commons Attribution License which permits any use, distribution, and reproduction in any medium, provided the original author(s) and the source are credited.

\section{References}

1. Heldin CH, Landström M, Moustakas A (2009) Mechanism of TGF-beta signaling to growth arrest, apoptosis, and epithelialmesenchymal transition. Curr Opin Cell Biol 21:166-176 
2. Rahimi RA, Leof EB (2007) TGF-beta signaling: a tale of two responses. J Cell Biochem 102:593-608

3. Li MO, Wan YY, Sanjabi S, Robertson AK, Flavell RA (2006) Transforming growth factor-beta regulation of immune responses. Annu Rev Immunol 24:99-146

4. Ueno M, Maeno T, Nomura M, Aoyagi-Ikeda K, Matsui H, Hara K et al (2011) Hypoxia-inducible factor- $1 \alpha$ mediates TGF- $\beta$-induced PAI-1 production in alveolar macrophages in pulmonary fibrosis. Am J Physiol Lung Cell Mol Physiol 300:L740-L752

5. Doi S, Zou Y, Togao O, Pastor JV, John GB, Wang L et al (2011) Klotho inhibits transforming growth factor- $\beta 1$ (TGF- $\beta 1$ ) signaling and suppresses renal fibrosis and cancer metastasis in mice. J Biol Chem 286:8655-8665

6. Di Sabatino A, Jackson CL, Pickard KM, Buckley M, Rovedatti L, Leakey NA et al (2009) Transforming growth factor beta signalling and matrix metalloproteinases in the mucosa overlying Crohn's disease strictures. Gut 58:777-789

7. Kanamaru Y, Nakao A, Mamura M, Suzuki Y, Shirato I, Okumura $\mathrm{K}$ et al (2001) Blockade of TGF-beta signaling in T cells prevents the development of experimental glomerulonephritis. J Immunol 166:2818-2823

8. Nakao A, Miike S, Hatano M, Okumura K, Tokuhisa T, Ra C et al (2000) Blockade of transforming growth factor beta/Smad signaling in $\mathrm{T}$ cells by overexpression of Smad7 enhances antigeninduced airway inflammation and airway reactivity. J Exp Med 192:151-155

9. Yamagiwa S, Gray JD, Hashimoto S, Horwitz DA (2001) A role for TGF-beta in the generation and expansion of CD4+CD25+ regulatory $\mathrm{T}$ cells from human peripheral blood. J Immunol 66:7282-7289

10. Feagins LA (2010) Role of transforming growth factor- $\beta$ in inflammatory bowel disease and colitis-associated colon cancer. Inflamm Bowel Dis 16:1963-1968

11. Monteleone G, Boirivant M, Pallone F, MacDonald TT (2008) TGF-beta1 and Smad7 in the regulation of IBD. Mucosal Immunol $1: \mathrm{S} 50-\mathrm{S} 53$

12. Becker C, Fantini MC, Neurath MF (2006) TGF-beta as a T cell regulator in colitis and colon cancer. Cytokine Growth Factor Rev 17:97-106

13. Monteleone G, Pallone F, MacDonald TT (2004) Smad7 in TGFbeta-mediated negative regulation of gut inflammation. Trends Immunol 25:513-517

14. Chung HL, Hwang JB, Park JJ, Kim SG (2002) Expression of transforming growth factor beta1, transforming growth factor type I and II receptors, and TNF-alpha in the mucosa of the small intestine in infants with food protein-induced enterocolitis syndrome. J Allergy Clin Immunol 109:150-154

15. Stadnicki A, Machnik G, Klimacka-Nawrot E, Wolanska-Karut A, Labuzek K (2009) Transforming growth factor-betal and its receptors in patients with ulcerative colitis. Int Immunopharmacol 9:761-766

16. Huang A, Gilmour JW, Imami N, Amjadi P, Henderson DC, AllenMersh TG (2003) Increased serum transforming growth factorbeta1 in human colorectal cancer correlates with reduced circulating dendritic cells and increased colonic Langerhans cell infiltration. Clin Exp Immunol 134:270-278

17. Christ M, McCartney-Francis NL, Kulkarni AB, Ward JM, Mizel DE, Mackall CL et al (1994) Immune dysregulation in TGF-beta 1-deficient mice. J Immunol 153:1936-1946

18. Saxena V, Lienesch DW, Zhou M, Bommireddy R, Azhar M, Doetschman $T$ et al (2008) Dual roles of immunoregulatory cytokine TGF-beta in the pathogenesis of autoimmunity-mediated organ damage. J Immunol 180:1903-1912

19. Bommireddy R, Pathak LJ, Martin J, Ormsby I, Engle SJ, Boivin GP et al (2006) Self-antigen recognition by TGF betal-deficient $T$ cells causes their activation and systemic inflammation. Lab Invest 86:1008-1019
20. Kader HA, Tchernev VT, Satyaraj E, Lejnine S, Kotler G, Kingsmore SF et al (2005) Protein microarray analysis of disease activity in pediatric inflammatory bowel disease demonstrates elevated serum PLGF, IL-7, TGF-beta1, and IL-12p40 levels in Crohn's disease and ulcerative colitis patients in remission versus active disease. Am J Gastroenterol 100:414-423

21. Xian CJ, Xu X, Mardell CE, Howarth GS, Byard RW, Moore DJ et al (1999) Site-specific changes in transforming growth factor-alpha and -betal expression in colonic mucosa of adolescents with inflammatory bowel disease. Scand J Gastroenterol 34:591600

22. IBD Working Group of the European Society for Paediatric Gastroenterology, Hepatology and Nutrition (ESPGHAN) (2005) Inflammatory bowel disease in children and adolescents: recommendations for diagnosis - the Porto Criteria. J Pediatr Gastroenterol Nutr 41:1-7

23. Hyams JS, Ferry GD, Mandel FS, Gryboski JD, Kibort PM, Kirschner BS et al (1991) Development and validation of a pediatric Crohn's disease activity index. J Pediatr Gastroenterol Nutr 12:439-447

24. Truelove SC, Witts LJ (1954) Cortisone in ulcerative colitis; preliminary report on a therapeutic trial. Br Med J 2:375-378

25. Wierzbicki PM, Adrych K, Kartanowicz D, Wypych J, Stanislawowski M, Zwolinska-Wcislo M et al (2009) Overexpression of the fragile histidine triad (FHIT) gene in inflammatory bowel disease. J Physiol Pharmacol 60(Suppl 4):57-62

26. Stanislawowski M, Wierzbicki PM, Golab A, Adrych K, Kartanowicz D, Wypych J et al (2009) Decreased toll-like receptor-5 (TLR-5) expression in the mucosa of ulcerative colitis patients. J Physiol Pharmacol 60(Suppl 4):71-75

27. Hume GE, Fowler EV, Lincoln D, Eri R, Templeton D, Florin TH et al (2009) Angiotensinogen and transforming growth factor beta1: novel genes in the pathogenesis of Crohn's disease. J Med Genet 43:e51

28. Wiercinska-Drapalo A, Flisiak R, Jaroszewicz J, Prokopowicz D (2005) Plasma interleukin-18 reflects severity of ulcerative colitis. World J Gastroenterol 11:605-608

29. Wiercińska-Drapało A, Flisiak R, Prokopowicz D (2001) Effect of ulcerative colitis activity on plasma concentration of transforming growth factor beta-1. Cytokine 14:343-346

30. Marek B, Kajdaniuk D, Mazurek U, Janczewska-Kazek E, Strzałka B, Beniowski M et al (2005) Quantitative assessment of mRNA TGF-beta1 in liver tissue in connection with serum mean daily level of TGF-1 in chronic hepatitis B patient. Pol Arch Med Wewn 114:738-745

31. Zein NN, Germer JJ, El-Zayadi AR, Vidigal PG (2004) Ethnic differences in polymorphisms of tumor necrosis factor-alpha, interleukin-10, and transforming growth factor-betal genes in patients with chronic hepatitis $\mathrm{C}$ virus infection. Am J Trop Med Hyg 70:434-437

32. Harrison RE, Berger R, Haworth SG, Tulloh R, Mache CJ, Morrell NW et al (2005) Transforming growth factor-beta receptor mutations and pulmonary arterial hypertension in childhood. Circulation 111:435-441

33. Monteleone G, Kumberova A, Croft NM, McKenzie C, Steer HW, MacDonald TT (2001) Blocking Smad7 restores TGF-beta1 signaling in chronic inflammatory bowel disease. J Clin Invest 108:601-609

34. Sturm A, Schulte C, Schatton R, Becker A, Cario E, Goebell H et al (2000) Transforming growth factor-beta and hepatocyte growth factor plasma levels in patients with inflammatory bowel disease. Eur J Gastroenterol Hepatol 12:445-450

35. Lawrance IC, Maxwell L, Doe W (2001) Inflammation location, but not type, determines the increase in TGF-betal and IGF-1 expression and collagen deposition in IBD intestine. Inflamm Bowel Dis 7:16-26 
36. Kanazawa S, Tsunoda T, Onuca E, Majami T, Kagiyama M, Kikuchi K (2001) VEGF, basic-FGF and TGF- $\beta$ in Crohn's disease and ulcerative colitis: a novel mechanism of chronic intestinal inflammation. Am J Gastroenterol 96:822-828

37. McKaig BC, Hughes K, Tighe PJ, Mahida YR (2002) Differential expression of TGF- $\beta$ isoforms by normal and inflammatory bowel disease intestinal myofibroblasts. Am J Physiol Cell Physiol 282: C172-C182

38. McKaig BC, McWilliams D, Watson SA, Mahida YR (2003) Expression and regulation of tissue inhibitor of metalloproteinase- 1 and matrix metalloproteinases by intestinal myofibroblasts in inflammatory bowel disease. Am J Pathol 162:1355-1360

39. Del Zotto B, Mumolo G, Pronio AM, Montesani C, Tersigni R, Boirivant M (2003) TGF-betal production in inflammatory bowel disease: differing production patterns in Crohn's disease and ulcerative colitis. Clin Exp Immunol 134:120 126

40. Bamias G, Nyce MR, De La Rue SA, Cominelli F (2005) New concepts in the pathophysiology of inflammatory bowel disease. Ann Intern Med 143:895-904 